\title{
Vascular Endothelial Growth Factor Receptor (VEGFR Flt-4) and Latent Membrane Protein (LMP-1) Expression in Nasopharyngeal Carcinoma
}

\author{
Abdul Qadar Punagi ${ }^{*}, 1$, Sofia Mubarika ${ }^{2}$ and Irawan Yusuf ${ }^{3}$ \\ ${ }^{I}$ Department of Otorhinolaryngology Medical Faculty, Hasanuddin University, Makassar, Indonesia \\ ${ }^{2}$ Department of Molecular Biology-Histology Medical Faculty-Gajah Mada University, Jokjakarta, Indonesia \\ ${ }^{3}$ Department of Molecular Biology-Physiology, Medical Faculty, Hasanuddin University, Makassar, Indonesia
}

\begin{abstract}
Background: Nasopharyngeal carcinoma (NPC) is a tumor arising from the epithelial cells that cover the surface and line the nasopharynx. NPC is a relatively rare malignancy in most parts of the world but it is endemic in many geographical regions, including Southern China, Southeast Asia and the Middle East/North Africa., Indonesia in particular, the incidence is relatively high, ranks $5^{\text {th }}$ out of 10 large tumors of the body and ranks $1^{\text {st }}$ in our department.

Objective: To study the relationship between the expressions of LMP1 and VEGFR (Flt-4) proteins compared with staging and histopathological features of nasopharyngeal carcinoma (NPC) in Indonesian population.

Materials and Methods: A cross sectional study with explorative approached was conducted in Makassar-Indonesia from July 2006 to August 2007. The expression of VEGFR (Flt-4) and LMP-1 proteins was examined by immuno histochemical with avidin-biotin methods staining in 45 NPC specimens.

Result: VEGFR (Flt-4) and LMP-1 were expressed in $100 \%$ and $42,1 \%$ of NPC specimens. No significant difference in correlation ( $>>0,05)$ between staging with VEGFR(Flt-4) and LMP-1 expression, these results indicated that VEGFR(Flt4) and LMP-1 were expressed during early stage to prepare for enhancing metastatic capacity to the later stage of NPC. There was negative correlation $(\mathrm{p}<0,05)$ between histopathological classification with VEGFR(Flt-4) and LMP-1 expression, this indicated that the expression of VEGFR(Flt-4) and LMP-1 was much higher in WHO type II (well differentiated) than WHO type III (undifferentiated). WHO type II well-known as more less sensitive to radiotherapy than WHO type III, according to the prognostic value; WHO type III better than type II. There was strong positive correlation $(\mathrm{r}=0,990, \mathrm{p}<0,05)$ between LMP-1 with VEGFR(Flt-4) expression, thereby LMP-1 induces production or expression of VEGF. No significant correlation was found between staging and histopathological features, VEGFR(Flt-4) and LMP-1 expression with alcohol, smoking, betel leaves-areca nuts, air pollution (wood's fire stove, mosquito repellent's smoke) and preservative foods (salted fish, canned food and smoked meat).

Conclusion: These results suggest that both VEGFR (Flt-4) and LMP-1 expressions are valuable prognostic markers for prognostic prediction in NPC patients.
\end{abstract}

Keywords: Nasopharyngeal carcinoma (NPC), VEGFR(Flt-4), LMP-1, Indonesia.

\section{INTRODUCTION}

Nasopharyngeal carcinoma (NPC) is a tumor arising from the epithelial cells that cover the surface and line the nasopharynx. NPC is a relatively rare malignancy in most parts of the world but it is endemic in many geographical regions, including Southern China, Southeast Asia and the Middle East/North Africa [1-3]. Ho [1] reported that NPC is the third most common malignancy among men, with an incidence of between 50 per 100,000 in the Guangdong Province of Southern China. Incidence is higher in the Chinese and Tunisian populations. NPC in Indonesia ranks $5^{\text {th }}$ out of 10 large tumors of the body and ranks $1^{\text {st }}$ in our ENT department. Nations with high risk are Eskimo,

*Address correspondence to this author at the Department of Otorhinolaryngology, Medical Faculty, Hasanuddin University, Makassar, Indonesia; Tel. +62 411590 737; Fax. +62 411590 737;

E-mail: qa_dar@yahoo.co.id
Tunisia, Philippines, Malaysia, Algeria and Indonesia. Rarely found in Caucasian, India, and Japan [2-4]. In Indonesia the incidence to date is not known. Health department data in 1980 showed the prevalence was 4.7 in 100.000 or estimated 7,000 to 8,000 cases in a year [5]. Profile data of nasopharyngeal carcinoma in Hasanuddin University Hospital Makassar, Indonesia from period of January 2000 to June 2007 revealed that nasopharyngeal carcinoma covered 33\% malignancy of ear, nose, and throat. Majority in $4^{\text {th }}$ and $5^{\text {th }}$ decades of life, male to female ratio is 2-3:1, the main histopathology finding was anaplastic carcinoma (type III WHO) accompanied by high tendency of metastasis [6].

NPC is often overlooked due to variation of symptoms and sign as well as difficulty to examine nasopharyngeal space, especially in Rosenmuller fossa, which is taken from the inventor, a German anatomist, Johan Christian 
Rosenmuller. Therefore, mortality rate is high. Patients usually come for treatment when the malignancy has developed to $3^{\text {rd }}$ degree or more. The range of life expectancy of 10 years range is $10 \%$ [7-9].

One of the risk factors that contributes to the process of somatic cell malignancy process is gene mutation. This mutation is caused by viral infection, radiation, and carcinogenic substances. The effect of gene mutations is uncontrolled cell proliferation and cell immortalization. EbsteinBarr Virus (EBV), as the name of the founder M. Anthony Epstein, Yvonne Barr, and B.G Achong in 1964, in cell cultured from Burkitt tumor. This virus originates from herpesviridae family, gamma herpes virus subfamily, lymphocryptovirus genera. Epstein-Barr Virus can be detected using serology, cell culture, and DNA technology [3, 4, 10-13].

Latent Membrane Protein-1 (LMP-1) products integral membrane (oncoprotein). LMP-1 gene is found in $65 \%$ nasopharyngeal carcinoma patients. LMP-1 EBV induces expression of COX-2 (cyclooxygenase) facilitated by $\mathrm{NF \kappa B}$ using CTAR1 and CTAR2 (carboxyl terminal activation region) on nasopharyngeal epithelial cell, producing Prostaglandin $\mathrm{E}_{2}$ and initiates increased production of Vascular Endothelial Growth Factor (VEGF) which plays a role in angiogenesis and lymphangiogenesis of NPC patients. VEGF-C is an important regulator of angiogenesis and lymphangiogenesis in the development, growth, and metastasis of malignant tumors including nasopharyngeal carcinoma. Some studies showed increased expression of VEGFR (Flt-4) which is a receptor of VEGF-C and associated with angiogenesis and lymphangiogenesis gradation, and poor prognosis in several human cancer [14-17]. Therefore, this research is conducted to find the potential relationship of VEGFR (Flt-4) and LMP-1 EBV expression on malignant tissue against stage, histopathology finding of nasopharyngeal carcinoma. Therefore a new more accurate treatment may be developed to reduce mortality and improved prognosis prediction

\section{RESEARCH OBJECTIVES}

To study the LMP-1 EBV and VEGF gene role on pathophysiology and NPC prognosis, expression of LMP-1 EBV and VEGFR (Flt-4) gene on NPC biopsy specimen and its correlation to Staging (TNM-UICC 2002) and histopathology findings (WHO 1979).

\section{MATERIALS AND METHODS}

This research is a cross sectional using explorative approach, conducted in Hasanuddin University hospital Makassar-Indonesia, Research unit and Department of Anatomical Pathology, Medical Faculty Gajah Mada University Jokjakarta from July 2006 to August 2007 Archival formalinfixed, paraffin-embedded specimens from 45 primary NPC patients were recruited. Tumors from the paraffin blocks were underwent tissue microarray construction before immunostaining. Paraffin sections were directly dissected for pathological staining and immunohistochemistry.

This study was approved by the Ethical Review Board of Medical Faculty Hasanuddin University.

\section{Clinical Examination}

A detailed history was considered using standardized questionnaire including race, age, gender, complained, first sign, habits of alcohol, smoking, betel quid chewing, salted fish, canned food, smoked meat, smoked mosquitoes repellent, wood smoke and family history.

Physical examination was performed for each patient including: ear, nose, and throat examination and nasoendoscopy assessment. And we complete the assessment was completed with biopsy, histopathology, chest x-ray, CTscan, bone-survey, and abdomen ultrasonography.

The inclusion criterion was the final finding of examination and assessments.

\section{Immunohistochemistry Examination}

Positive paraffin block biopsy of NPC cut with $5 \mu \mathrm{m}$ thickness and placed in a glass object (precleaned white glass with poly L lysine coated) and left for one night in 37$40^{\circ} \mathrm{C}$ incubator. Then the specimen underwent de-paraffin. Immunohistochemistry examination conducted using antiVEGFR (FLT-4 monoclonal antibody (Lab. Viscon) (1:200). For LMP-EBV, anti-LMP-1 EBV monoclonal antibody (Novo Castra) (1:200) was used. Based on avidin-biotinperoxidase technique.

Positive expression of LMP-1 was seen as brown granula on cytoplasma and membrane, while on VEGFR was seen as brown granule on cytoplasma. Expression measurement was conducted using binocular microscope magnified to 100-200 times on random field view and counted in 100-200 cells. Semi quantitative measurements of VEGFR(Flt-4) and LMP1 expression are; 0:negative, $1+$ : weak ( $<10 \%$ of expression), +2 : moderate $(10-25 \%)$, and +3 : strong (expression $>25 \%)$.

\section{RESULTS}

\section{Sample Characteristic}

Sample characteristic can be seen in Table 1. Sample mean age was $45,8 \pm 13,7$ years old, the youngest was 17 years old and the oldest was 72 years old. There were 38 male $(84.4 \%)$ and 7 female $(15.6 \%)$. The main races were Bugis $21(46.7 \%)$, and Makassar 12 (26.6\%). The first most first complained were nose bleeding in $16(35.56 \%)$, and headache in $9(20 \%)$. The most complained were neck mass in $24(53.3 \%)$ and nasal obstruction in $10(22.2 \%)$

\section{Nasopharyngeal Carcinoma Staging}

Nasopharyngeal carcinoma staging is based on TNMUICC 2002 [18] in Table 2. Most stage found were stage III: 19 cases $(42.2 \%)$, stage IV: 14 cases $(31.2 \%)$

\section{Histopathology Finding}

Histopathology finding based on WHO 1979 [8] in Table 3, Type II WHO: 15 cases (33.3\%), and Type III WHO: 30 cases $(66.7 \%)$.

\section{VEGFR(Flt-4) and LMP-1 Expression}

The expression of LMP-1 (Fig. 1) and VEGFR (FLt-4) (Fig. 2) on nasopharyngeal biopsy was found in $41,1 \%$ in type III WHO and almost 100\% LMP-1 (Fig. 3) and VEGFR (Flt-4) (Fig. 4) in type II WHO respectively.

\section{DISCUSSION}

There was no significant correlation found between NPC staging and expression of VEGFR(Flt-4) and LMP-1 
( $p>0.05$ ), which means that the expression of VEGFR(flt-4) and LMP-1 expression is higher on early stage, which is required for preparing metastasis. There were significant inverse relationship between histopathology and VEGFR(Flt-4) and LMP-1 expression $(\mathrm{P}<0.05)$, which means that the expression of VEGFR(Flt-4) and LMP-1 expression is higher in type II WHO (Figs. 3, 4) (good differentiation) compared to type III WHO (poor differentiation), where the prognosis of type II WHO based on tumor response against radiation therapy is poorer than type III WHO. There was strong relationship $(\mathrm{p}<0.05)$ between VEGFR(Flt-4) and LMP-1 expressions, which means that LMP-1 expression increased as the expression of VEGFR(Flt-4) increased, therefore LMP-1 may increase (strong regulator) production of VEGFR(Flt-4). There was no significant relationship $(\mathrm{p}<0.05)$ between clinical findings including staging, histopathology, VEGFR(Flt-4) and LMP1 expression against alcohol, cigarette smoking, betel-quid chewing, pollutant (smoked mosquitoes repellent and wood smoke) and preserved food (salted fish, canned food, and smoked meat).

Table 1. Sample Characteristic

\begin{tabular}{|c|c|c|c|c|c|c|}
\hline \multirow{2}{*}{ Characteristic } & \multicolumn{6}{|c|}{ Group } \\
\hline & Cases & $\%$ & Control & $\%$ & Total & $\%$ \\
\hline \multicolumn{7}{|l|}{ Gender } \\
\hline Male & 38 & 84.44 & 28 & 62.22 & 66 & 73.33 \\
\hline Female & 7 & 15.56 & 17 & 37.78 & 24 & 26.67 \\
\hline Total & 45 & 100.00 & 45 & 100.00 & 90 & 100.00 \\
\hline \multicolumn{7}{|l|}{ Age (Years) } \\
\hline$<27$ & 4 & 8.89 & 5 & 11.11 & 9 & 10.00 \\
\hline $27-36$ & 8 & 17.78 & 17 & 37.78 & 25 & 27.78 \\
\hline $37-46$ & 12 & 26.67 & 12 & 26.67 & 24 & 26.67 \\
\hline $47-56$ & 9 & 20.00 & 7 & 15.56 & 16 & 17.78 \\
\hline $57-66$ & 10 & 22.22 & 3 & 6.67 & 13 & 14.44 \\
\hline$>66$ & 2 & 4.44 & 1 & 2.22 & 3 & 3.33 \\
\hline Total & 45 & 100.00 & 45 & 100.00 & 90 & 100.00 \\
\hline \multicolumn{7}{|l|}{ Race } \\
\hline Bugis & 21 & 46.67 & 16 & 35.56 & 37 & 41.11 \\
\hline Makassar & 12 & 26.67 & 11 & 24.44 & 23 & 25.56 \\
\hline Toraja & 6 & 13.33 & 3 & 6.67 & 9 & 10.00 \\
\hline Gorontalo & 2 & 4.44 & 2 & 4.44 & 4 & 4.44 \\
\hline Mandar & 1 & 2.22 & 4 & 8.89 & 5 & 5.56 \\
\hline Minahasa & 1 & 2.22 & 0 & 0.00 & 1 & 1.11 \\
\hline Banjar & 1 & 2.22 & 0 & 0.00 & 1 & 1.11 \\
\hline Java & 1 & 2.22 & 2 & 4.44 & 3 & 3.33 \\
\hline Ambon & 0 & 0.00 & 4 & 8.89 & 4 & 4.44 \\
\hline Bali & 0 & 0.00 & 2 & 4.44 & 2 & 2.22 \\
\hline Chinese & 0 & 0.00 & 1 & 2.22 & 1 & 1.11 \\
\hline Jumlah & 45 & 100.00 & 45 & 100.00 & 90 & 100.00 \\
\hline
\end{tabular}

\section{CONCLUSION}

LMP-1 is a strong regulator to $\operatorname{VEGFR(Flt-4),~associated~}$ with the prognosis of NPC, marked with the expression on type II WHO compared to type III WHO. Although there were no correlation between clinical finding including staging, histopathology finding, VEGFR(Flt-4) and LMP-1 expression.

Table 2. Staging of Nasopharyngeal Carcinoma

\begin{tabular}{|c|c|c|}
\hline Based on Stage (T, N, M-UICC 2002) & Total & $\%$ \\
\hline Stage I & 2 & 4.44 \\
\hline \multicolumn{3}{|l|}{ Stage II } \\
\hline II A & 2 & 4.44 \\
\hline II B & 8 & 17.78 \\
\hline Stage III & 19 & 42.22 \\
\hline \multicolumn{3}{|l|}{ Stage IV } \\
\hline IV A & 5 & 11.11 \\
\hline IV B & 6 & 13.33 \\
\hline IV C & 3 & 6.67 \\
\hline Total & 45 & 100.00 \\
\hline
\end{tabular}

Table 3. Histopathology Finding

\begin{tabular}{|c|c|c|}
\hline Histopathology Finding & Total & \% \\
\hline \hline Type 3 WHO & 30 & 66.67 \\
\hline Type 2 WHO & 15 & 33.33 \\
\hline Type 1 WHO & 0 & 0.00 \\
\hline Total & $\mathbf{4 5}$ & $\mathbf{1 0 0 . 0 0}$ \\
\hline
\end{tabular}

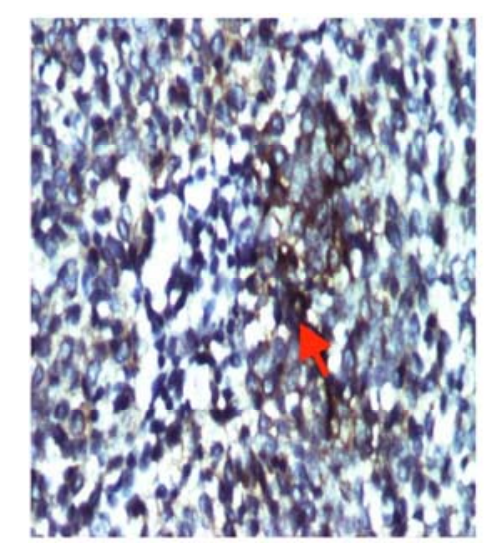

Fig. (1). Expression of LMP-1, 200x, WHO3, St.IVC.

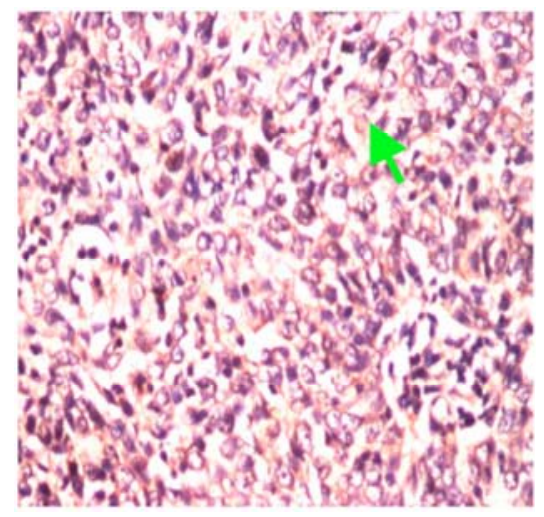

Fig. (2). Expression of VEGFR (Flt-4), 200x, WHO3, St.IVC. 


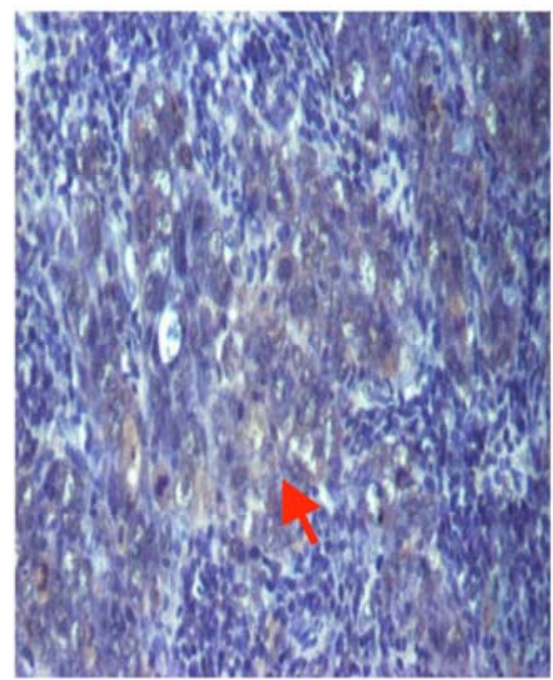

Jokjakarta) and Masyita Gaffar, M.D., Ph.D. (Department of Otorhinolaryngology Medical Faculty Hasanuddin University).

\section{REFERENCES}

[1] Ho HC. An epidemiologic and clinical study of nasopharyngeal carcinoma. Int J Radiat Oncol 1978; 4(3-4): 183-98.

[2] Choi PHK, Suen MWM, Path MRC, et al. Nasopharyngeal carcinoma: genetic changes, epstein-barr virus infection, or both Cancer 1993; 72(7): 2873-5.

[3] Tune CE, Liavaag PG, Freeman JL, et al. Nasopharyngeal brush biopsies and detection of nasopharyngeal cancer in high-risk population. J Natl Cancer Inst 1999; 91(9): 796-9.

[4] Mongan AE, Harahap AR. Onkogenesis Virus Epstein-Barr pada Limfoma Burkitt dan Karsinoma Nasofaring. Bagian Patologi Klinik. Jakarta: Universitas Indonesia 1998; pp. 18-21.

[5] Rasyid A. Karsinoma nasofaring: Penatalaksanaan radiodiagnostik. Maj Kedokt Indon 2000; 50(8): 400-1.

[6] Punagi AQ. Profil Karsinoma Nasofaring di Rumah Sakit Pendidikan Fakultas Kedokteran Universitas Hasanuddin Periode Januari 2004-Juni 2007. Makassar: Bagian THT Fakultas Kedokteran Universitas Hasanuddin 2007.

Fig. (3). Expression of LMP 1, 200x, WHO2, St II B.

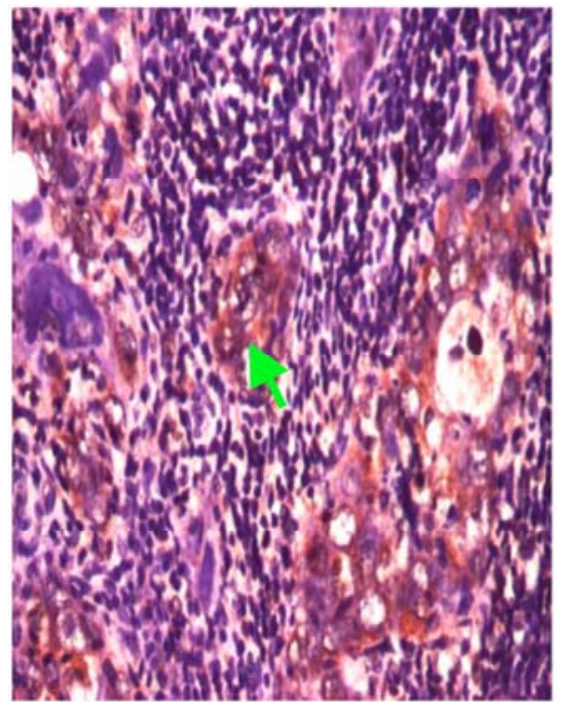

[7] Liebowitz D. Nasopharyngeal Carcinoma: The Epstein-barr virus association. Semin Oncol 1994; 21(3): 376-80.

[8] Chan ATC, Teo PML, Johnson PJ. Nasopharyngeal carcinoma Ann Oncol 2002; 13: 1007-9.

[9] Punagi AQ. Evaluasi dan Biopsi Nasofaring Secara Endoskopis pada Kasus Klinis Karsinoma Nasofaring. Karya Akhir Program Pendidikan Dokter Spesialis-1 THT. Fakultas Kedokteran Universitas Hasanuddin 1997.

[10] Coebergh JWW, Vandenbroucke JP. Aspek Epidemiologik Kanker.dalam: Onkologi;terjemahan ke-5 Onkologie. CJH van de Velde, FT Bosman (Red). Leiden. Yogyakarta 1999; pp. 37-9.

[11] Chang KP, Hao SP, Lin SY, et al. A lack of association between p53 mutations and recurrent nasopharyngeal carcinomas refractory to radiotherapy. Laryngoscope 2002; 112: 2015-8.

[12] Yoshizaki T, Wakisaka N, Pagano JS. Epstein Barr Virus Invasion and Metastasis. From: Epstein-Barr Virus. Robertson ES, Ed. University of Pensylvania Medical School, Philadelphia. Caister Academic Press 2005; pp. 171-89.

[13] Sun D. Epigenetics in Nasopharyngeal Carcinoma. DisertationKarolinska Institutet, Stockholm, Sweden 2006; pp. 32-4.

[14] Lee SJ, Lee SY, Jeon HS, et al. Vascular endothelial growth factor gene polymorphisms and risk of primary lung cancer. Cancer Epidemiol Biomarkers Prev 2005; 14(3): 271-574.

[15] Steven A, Soden J, Brenchley PE, et al. Haplotype analysis of polymorphic human vascular endothelial growth factor gene promoter. Cancer Res 2003; 15(2): 812-6.

Fig. (4). Expression of VEGFR(Flt-4)200x, WHO2, St IIB.

\section{SUGGESTION}

[16] Yancopoulos GD, Davis S, Gale NW, et al. Vascular-specific growth factors and blood vessels formation. Nature 2000; 407: 2428.

Wide research using larger sample covering various aspects that affect prognosis and multidisciplinary work. The expression of VEGFR(Flt-4) and LMP-1 expression can be considered as one predictor of NPC prognosis.

[17] Liu ZE, Sun XD, Wu JM. Expression and significance of VEGF-C and FLT-4 in gastric cancer. World J Gastroenterol 2004; 10(3): $352-5$.

[18] Sobin LH, Wittekind C. TNM -classification of malignant tumours. UICC-International Union Against Cancer. Wiley-Liss Pub. $6^{\text {th }}$ ed. 2002.

The authors confirm that this article content has no conflict of interest.

\section{ACKNOWLEDGEMENTS}

Thanks to Harijadi, M.D. (Department of Anatomical Pathology Medical Faculty Gajah Mada University 